\title{
POTENSI AGROINDUSTRI BERBASIS KELAPA UNTUK PEMBERDAYAAN EKONOMI MASYARAKAT DI KABUPATEN PANGANDARAN - JAWA BARAT
}

\section{A POTENCYOF COCONUT BASED AGROINDUSTRY FOR THE EMPOWERMENT OF THE ECONOMY OF THE SOCIETY IN PANGANDARAN DISTRICT - WEST JAVA}

\author{
Abidin $^{1 *}$, Sukardi $^{2)}$, Djumali Mangunwidjaja ${ }^{2)}$, Muhammad Romli ${ }^{2)}$ \\ ${ }^{1)}$ Program Studi Teknik Industri, Fakultas Sains dan Teknologi,Universitas Buddhi Dharma Tangerang \\ J1. Imam Bonjol No. 41 Karawaci Ilir, Kota Tangerang, Banten, Indonesia \\ Email : abidin@buddhidharma.ac.id \\ Departemen Teknologi Industri Pertanian, Fakultas Teknologi Pertanian, Institut Pertanian Bogor \\ Kampus IPB Darmaga, P.O.Box 220, Bogor, Indonesia
}

Makalah: Diterima 28 Juni 2018; Diperbaiki 23 Agustus 2018; Disetujui 29 Agustus 2018

\begin{abstract}
Pangandaran district is a district that has the third largest coconut tree plantation area in West Java, and coconut is made as one of the potential regional prime commodities. This research objective was to discover four aspects on coconut agroindustry, namely the availability of raw material, distribution, product's prospective, and economic empowerment of society. The method used in this research was descriptive method, while survey and questionnaire spreading were used. To find out the potential availability of raw materials, secondary data were used,which were proceeded with forecasting moving average method. Spreading of coconut agroindustry was mapped for several sub-districts, according to primary or secondary data. Determination of prospective product were done by Technique for Order Performance of Similarity to Ideal Solution (TOPSIS). Potential of economic empowerment was obtained by analysis of profit cost ratio. Refer to the research results, coconut agroindustry had big potential in empowerment of the social economy. This potency can be seen by the amount of availability and certainty of coconut as raw material, the quality of the resulting coconut, availability of human resources, breadth of market section, infrastructure and means of transportation, supporting by local people, then government policy that supporting in growth and development of coconut agroindustry. The coconut agroindustry was spread in a whole sub-disctrict, and the most of it was located in Cimerak Sub-District. The most prospective product was coconut sugar, that is one of products that have big potential and profitable for empowerment of the social economy.
\end{abstract}

Keywords: agroindustry, coconut, economic empowerment, Pangandaran Regency

\section{ABSTRAK}

Kabupaten Pangandaran adalah daerah yang memiliki perkebunan kelapa terluas ketiga di Jawa Barat, serta menjadikan komoditas kelapa sebagai salah satu potensi unggulan daerah.Penelitian ini bertujuan untuk mengidentifikasi dan menganalisis agroindustri berbasis kelapa berdasarkan empat aspekyakni: potensi ketersediaan bahan baku, sebaran, produk prospektif, dan potensinya untuk pemberdayaan ekonomi masyarakat di Kabupaten Pangandaran.Untuk mengidentifikasi potensi ketersediaan bahan baku, digunakan data sekunder yang diolah menggunakan metode peramalan moving average. Penyebaran agroindustri berbasis kelapa dipetakan pada tingkat kecamatan, berdasarkan data primer maupun sekunder.Penentuan produk prospektif dilakukan dengan menggunakan metode Technique for Order Performance of Similarity to Ideal Solution (TOPSIS). Potensi pemberdayaan ekonomi diperoleh melalui analisis profit cost ratio serta analisis deskriptif. Dari hasil penelitian diketahui bahwa agroindustri berbasis kelapa di Kabupaten Pangandaran memiliki potensi yang besar dalam pemberdayaan ekonomi masyarakat. Potensi dapat dilihat dari jumlah ketersediaan dan kepastian pasokan bahan baku kelapa, kualitas kelapa yang dihasilkan, ketersediaan sumber daya manusia, pangsa pasar yang luas, infrastruktur dan sarana transportasi, dukungan masyarakat sekitar, hingga adanya kebijakan pemerintah daerah yang mendukung tumbuh kembangnya agroindustri berbasis kelapa. Agroindustri berbasis kelapa tersebar di seluruh kecamatan dengan jumlah terbanyak terdapat di Kecamatan Cimerak. Produk yang paling prospektif adalah gula kelapa, sekaligus sebagai salah satu produk yang memiliki potensi besar dan menguntungkan untuk pemberdayaan ekonomi masyarakat di Kabupaten Pangandaran Jawa Barat.

Kata kunci: agroindustri, kelapa, pemberdayaan ekonomi, Kabupaten Pangandaran

\section{PENDAHULUAN}

Provinsi Jawa Barat merupakan provinsi yang memiliki perkebunan kelapa terluas dan tingkat produksi terbanyak ketiga di Pulau Jawa setelah
Jawa Timur dan Jawa Tengah.Luas perkebunan kelapanya lebih dari 178 ribu ha dan produksi tidak kurang dari 106 ribu ton setara kopra (Direktorat 
Jenderal Perkebunan, 2017). Data dari setiap provinsi di Pulau Jawa dapat dilihat pada Tabel 1.

Sementara itu, menurut data dari BPS (2017) Pangandaran merupakan kabupaten yang menempati urutan ketiga di Jawa Barat dalam hal luas perkebunan kelapa, tingkat produksi, maupun produktivitasnya. Data dari 5 (lima) kabupaten yang memiliki perkebunan kelapa terluas di Provinsi Jawa Barat dapat dilihat pada Tabel 2.

Menurut BPS (2017), perkebunan kelapa di Kabupaten Pangandaran merupakan perkebunan rakyat yang dimiliki oleh 65.291 Kepala Keluarga (KK). Sebagian besar perkebunan kelapa rakyat tersebut berada di area pesisir Kabupaten Pangandaran.Tanaman kelapa memiliki sejarah yang panjang bagi masyarakat yang tinggal di daerah pesisir (Abuya, 2013; Moorthi, 2012). Berbagai produk dapat dihasilkan dari tanaman kelapabaik dalam skala industri kecil, menengah maupun besar. Industri-industri tersebut di antaranya kopra, minyak kelapa, oleokimia, kelapa parut, gula kelapa, dan industri produk ikutan seperti bungkil, tempurung, sabut, dan nata de coco (Amin dan Prabandano, 2014). Prospek dan potensi dari produk-produk tersebut menurut Sivapragasam (2008), ditentukan oleh: (1) adanya permintaan global yang dipengaruhi oleh populasi, pendapatan dan harga, (2) pertumbuhan pasar regional khususnya di China dan Timur Tengah, (3) adanya penggunaan baru seperti pada industri makanan organik, obat-obatan, oleokimia, biodiesel, pelumas, dan produk-produk turunan lainnya.

Di samping itu, keberadaan dan pemanfaatan tanaman kelapa bagi sebagian penduduk sudah berlangsung dalam kurun waktu yang sangat lama (Abuya, 2013), khususnya bagi penduduk yang tinggal di daerah tropis (Moorthi,
2012). Jika dilihat dari perannya, komoditas kelapa memiliki peran yang besar terhadap perekonomian nasional yakni mampu memberikan kontribusi sebesar $0,36 \%$ terhadap perolehan ekspor nasional (Wulandari dan Ma'arif, 2009). Pertumbuhan ekonomi suatu wilayah yang didukung oleh pemanfaatan sumber daya alam secara baikakan memberikan dampak positif bagi pencapaian tujuan pembangunan di wilayah tersebut (Zulgani et al., 2014). Salah satu tujuan yang harus dicapai adalah memaksimalkan keuntungan atau manfaat ekonomi regional (Moorthi, 2012).

Selanjutnya, dengan adanya otonomi daerah diharapkan pertumbuhan ekonomi dan potensi wilayah mampu menggerakkan dan memacu proses percepatan pembangunan untuk meningkatkan pendapatan masyarakat serta mewujudkan pemerataan pembangunan antar daerah (Rusdi, 2014). Pemetaan agroindustri berdasarkan komoditas pertanian potensial menjadi suatu hal yang penting bagi pemerintah daerah dalam menetapkan strategi pembangunan perekonomian masyarakatnya (Elida, 2017). Pemetaan dilakukan pada tingkat kecamatan (Nasir dan Yuslinaini, 2017). Penentuan kawasan dapat dilakukan berdasarkan komoditas unggulan (Supratma dan Erli, 2013).

Berdasarkan uraian di atas, maka perlu dilakukan analisis potensi agroindustri berbasis kelapa untuk pemberdayaan ekonomi masyarakat di Kabupaten Pangandaran, Jawa Barat. Adapun tujuan dari penelitian ini adalah untuk mengidentifikasi dan menganalisis agroindustri berbasis kelapa di Kabupaten Pangandaran dalam hal: (1) potensi ketersediaan bahan baku, (2) sebaran, (3) produk prospektif, dan (4) potensi agroindustri berbasis kelapa untuk pemberdayaan ekonomi masyarakat.

Tabel 1. Luas lahan perkebunan dan tingkat produksi kelapa setiap provinsi di Pulau Jawa

\begin{tabular}{crrrrrr}
\hline \multirow{2}{*}{ Provinsi } & \multicolumn{3}{c}{ Luas Lahan (ha) } & \multicolumn{3}{c}{$\begin{array}{c}\text { Tingkat Produksi } \\
\text { (ton setara kopra) }\end{array}$} \\
\cline { 2 - 7 } & \multicolumn{1}{c}{$\mathbf{2 0 1 5}$} & \multicolumn{1}{c}{$\mathbf{2 0 1 6}$} & \multicolumn{1}{c}{$\mathbf{2 0 1 7}$} & $\mathbf{2 0 1 5}$ & $\mathbf{2 0 1 6}$ & $\mathbf{2 0 1 7}$ \\
\hline DKI Jakarta & - & - & - & - & - & - \\
Jawa Barat & 178.027 & 177.867 & 177.398 & 106.408 & 106.184 & 106.078 \\
Banten & 81.012 & 80.850 & 80.628 & 45.731 & 45.626 & 45.395 \\
Jawa Tengah & 230.014 & 228.618 & 225.252 & 181.131 & 170.271 & 158.749 \\
DI Yogyakarta & 43.017 & 42.834 & 42.754 & 50.383 & 49.967 & 49.642 \\
Jawa Timur & 818.492 & 816.842 & 813.289 & 259.502 & 255.655 & 273.200 \\
\hline
\end{tabular}

Sumber: Direktorat Jenderal Perkebunan (2017)

Tabel 2. Luas lahan perkebunan dan tingkat produksi kelapa dari lima kabupaten yang ada di Jawa Barat

\begin{tabular}{ccccccc}
\hline \multirow{2}{*}{ Provinsi } & \multicolumn{2}{c}{ Luas Lahan $($ Ha) } & \multicolumn{2}{c}{$\begin{array}{c}\text { Tingkat Produksi } \\
\text { (Ton Setara Kopra) }\end{array}$} & \multicolumn{2}{c}{$\begin{array}{c}\text { Tingkat Produktivitas } \\
\text { (Ton/Ha) }\end{array}$} \\
\cline { 2 - 7 } & $\mathbf{2 0 1 5}$ & $\mathbf{2 0 1 6}$ & $\mathbf{2 0 1 5}$ & $\mathbf{2 0 1 6}$ & $\mathbf{2 0 1 5}$ & $\mathbf{2 0 1 6}$ \\
\hline Tasikmalaya & 30,643 & 30,687 & 27,380 & 27,380 & 0,89 & 0,89 \\
Pangandaran & 34,640 & 25,354 & 19,000 & 12,623 & 0,55 & 0,50 \\
Ciamis & 32,647 & 32,647 & 19,719 & 19,998 & 0,60 & 0,61 \\
Sukabumi & 9,264 & 4,261 & 2,074 & 2,011 & 0,22 & 0,47 \\
Cianjur & 8,004 & 8,003 & 4,106 & 4,005 & 0,51 & 0,50 \\
\hline
\end{tabular}

Sumber: BPS, 2017(diolah) 
Ruang lingkup dalam analisis potensi ini meliputi seluruh agroindustri berbasis kelapa yang berada di Kabupaten Pangandaran, baik industri mikro kecil dan menengah (IMKM) maupun besar, dan dikaitkan dengan Kabupaten Pangandaran sebagai Kawasan Strategis Provinsi (KSP) penanganan ekonomi, dalam rangka mewujudkan wilayah Jawa Barat bagian Selatan menjadi kawasan agribisnis, agroindustri, industri kelautan dan pariwisata terpadu. Sementera itu, produk unggulan dihasilkan dari hasil penyebaran kuesioner terhadap sejumlah responden yang kompeten dan netral serta kuesioner yang disebarkan kepada sejumlah wisatawan yang datang ke berbagai objek wisata yang ada di Kabupaten Pangandaran. Terakhir, guna memberikan gambaran potensi agroindustri berbasis kelapa untuk pemberdayaan ekonomi masyarakat di Kabupaten Pangandaran akan dilakukan analisis terhadap produk prospektif yang dihasilkan pada tahap sebelumnya.

\section{METODE PENELITIAN}

\section{Kerangka Pemikiran}

Sumber daya perkebunan terbesar yang saat ini dimiliki oleh Kabupaten Pangandaran adalah kelapa (BPS, 2017). Selain itu, menurut data dari Dinas Tenaga Kerja, Industri, dan Transmigrasi (Disnakerintrans) Kabupaten Pangandaran (2017), agroindustri berbasis kelapa juga menjadi salah satu sektor andalan, terbukti dengan banyaknya agorindustri berbasis kelapa yang tersebar di setiap kecamatan dengan menghasilkan berbagai produk. Kondisi seperti ini memberikan gambaran akan adanya potensi pemberdayaan ekonomi masyarakat di Kabupaten Pangandaran. Kerangka pemikiran selengkapnya dapat dilihat pada Gambar 1 .

\section{Tata Laksana}

Penelitian diawali dengan melakukan analisis situasional potensi ketersediaan bahan baku agroindustri berbasis kelapa. Pada tahap ini digunakan data sekunder dari Badan Pusat Statistik (BPS) Jawa Barat dan Dinas Pertanian (Distan) Kabupaten Pangandaran tahun 2017. Data tersebut selanjutnya diolah menggunakan metode peramalan moving average. Metode moving average efektif diterapkan apabila data permintaan pasar terhadap produk akan tetap stabil sepanjang waktu (Gaspersz, 2005). Dari proses ini akan dihasilkan gambaran ketersediaan bahan baku baik berupa buah maupun turunannya. Selain itudihitung juga potensi ketersediaan bahan baku berupa nira kelapa sebagai bahan baku gula kelapa, dan wawancara dengan 10 praktisi guna mengetahuai faktor-faktor lain yang berpotensi mendorong terhadap pertumbuhan agroindustri berbasis kelapa.

Tahap selanjutnya melakukan pemetaan sebaran agroindustri berbasis kelapapada tingkat kecamatan berdasarkan kepada data primer maupun sekunder yang diperoleh dari Disnakerintrans tahun 2017. Data primer diperoleh melalui survey langsung terhadap sepuluh kecamatan yang ada di Kabupaten Pangandaran, wawancara dengan Kepala Seksi Ekonomi dan Pembangunan di setiap kecamatan, pejabat yang berwenang pada dinasdinas terkait dan beberapa orang pelaku agorindustri berbasis kelapa. Pada tahapan ini akan diperoleh hasil berupa jenis dan jumlah agroindustri berbasis kelapa yang ada di setiap kecamatan. Selain itu, dilakukan juga analisis terhadap prosentase perubahan pada setiap jenis agroindustri berbasis kelapa, baik di tingkat kecamatan maupun kabupaten.

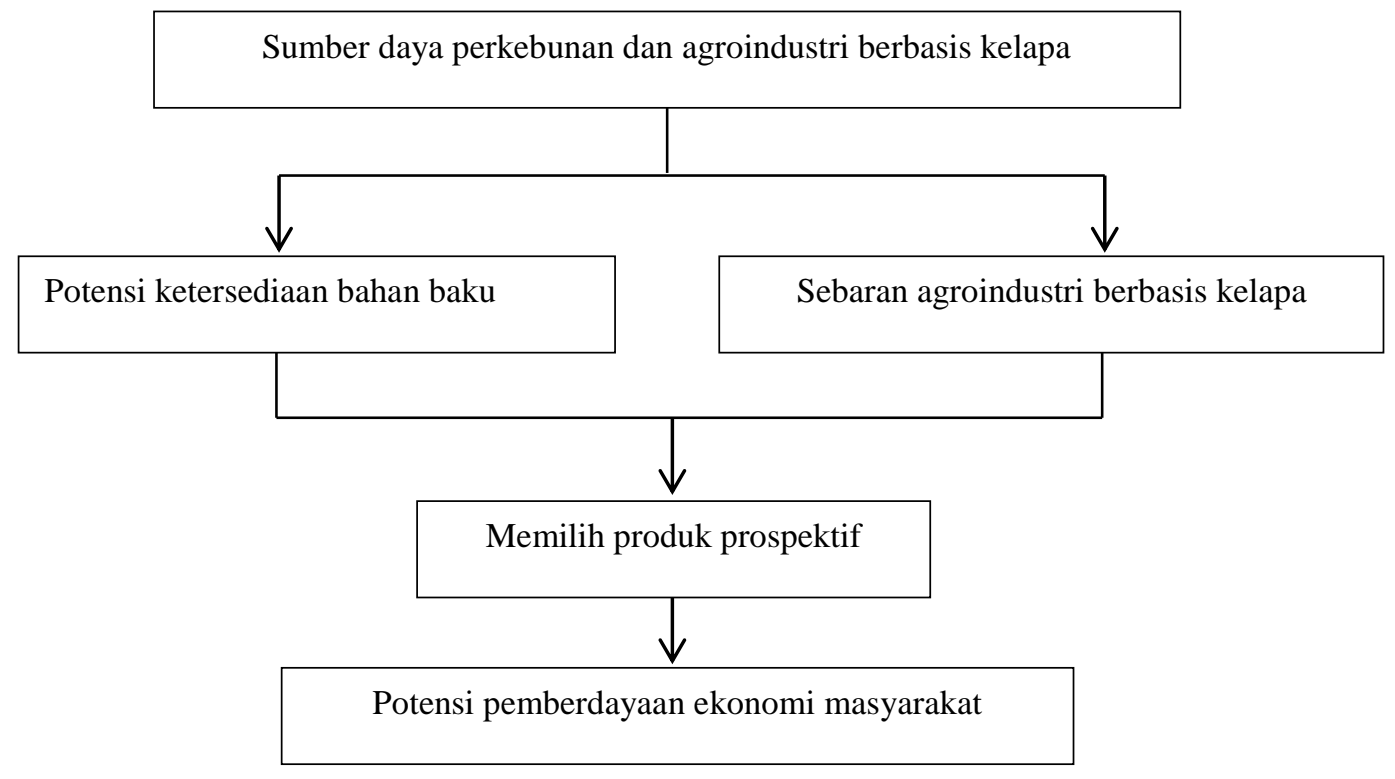

Gambar 1. Kerangka pemikiran 
Sementara itu, untuk menentukan produk prospektif, dilakukan penyebaran kuesioner tertutup terhadap tiga orang responden yang kompeten dan netral yakni pejabat di Disnakerintrans bidang Industri Kimia Agro dan Hasil Hutan (IKAHH), Sekretariat Daerah (Setda) Bidang Perekonomian, dan Business Development Centre (BDC) Kabupaten Pangandaran. Data hasil pengisian kuesioner tersebut dihitung rata-rata geometriknya (mean geometric) dan selanjutnya diolah dengan menggunakan metode Technique for Order Performance of Similarity to Ideal Solution (TOPSIS). Metode TOPSIS digunakan karena memiliki konsep sederhana dan mudah dipahami, komputasinya efisien dan memiliki kemampuan untuk mengukur kinerja relatif dari alternatifalternatif keputusan dalam bentuk matematis yang sederhana (Sari et al., 2014), dan dapat digunakan untuk menentukan alternatif terbaik berdasarkan kriteria yang dipertimbangkan (Rukmayadi, 2016).

Formulasi untuk menghitung rata-rata geometrik menurut Marimin dan Maghfiroh (2013) adalah:

$$
\overline{X_{G}}=\sqrt[n]{\prod_{i=1}^{n} X_{i}}
$$

Dimana:

$$
\begin{array}{rll}
\overline{X_{G}} & = & \text { rata-rata-rata geometrik } \\
\mathrm{n} & = & \text { Jumlah responden } \\
\mathrm{X}_{\mathrm{i}} & = & \text { Penilaian oleh responden ke-i } \\
\Pi & = & \text { perkalian }
\end{array}
$$

Menurut Chen (2000) dan Windarto (2017), untuk menentukan kedekatan relatif dari suatu alternatif, metode TOPSIS menggunakan prinsip bahwa alternatif yang terpilih harus mempunyai jarak terdekat dan solusi ideal positif dan terjauh dari solusi ideal negatif dari sudut pandang geometris dengan menggunakan jarak euclidean. Adapun langkah-langkah algoritmanya menurut Hwang dan Yoon (1981) adalah:

a. Menentukan normalisasi matriks keputusan. Nilai ternormalisasi $\mathrm{r}_{\mathrm{ij}}$ dihitung dengan rumus:

$$
r_{i j}=\frac{x_{i j}}{\sum_{i=1}^{m} x_{i j}^{2}}
$$

Keterangan:

$$
\begin{aligned}
& i=1,2, \ldots, m . \\
& j=1,2, \ldots, n .
\end{aligned}
$$

b. Menetukan bobot ternormalisasi matriks keputusan. Nilai bobot ternormalisasi $\mathrm{y}_{\mathrm{ij}}$ sebagai berikut:

$$
y_{i j}=w_{i j} \cdot r_{i j}
$$

Keterangan:

$\mathrm{i}=1,2, \ldots, \mathrm{m}$.

$\mathrm{j}=1,2, \ldots, \mathrm{n}$.

$$
\begin{aligned}
& A^{+}=y_{1}^{+}, y_{2}^{+}, \ldots, y_{n}^{+} ; \\
& A^{-}=y_{1}^{-}, y_{2}^{-}, \ldots, y_{n}^{-} ;
\end{aligned}
$$

dengan nilai $\mathrm{j}=1,2, \ldots, \mathrm{n}$

Jarak antara alternatif Ai dengan solusi ideal positif dirumuskan sebagai berikut:

Keterangan:

$$
D_{i}^{+}=\sqrt{\sum_{j=1}^{n}\left(y_{i}^{+}-y_{i j}\right)^{2}}
$$

$$
\mathrm{i}=1,2, \ldots, \mathrm{m}
$$

Jarak antara alternatif $A_{i}$ dengan solusi ideal negatif dirumuskan sebagai berikut:

$$
D_{i}^{-}=\sqrt{\sum_{j=1}^{n}\left(y_{i j}-y_{i}^{-}\right)^{2}}
$$

Keterangan:

$$
\mathrm{i}=1,2, \ldots, \mathrm{m}
$$

Untuk menentukan nilai prefensi setiap alternatif $\left(\mathrm{V}_{\mathrm{i}}\right)$ digunakan formulasi sebagai berikut:

$$
V_{i}=\frac{D_{i}^{-}}{D_{i}^{-}+D_{i}^{+}}
$$

dimana $\mathrm{i}=1,2, \ldots, \mathrm{m}$

Nilai $V_{i}$ yang lebih besar menunjukkan bahwa alternatif $\mathrm{A}_{\mathrm{i}}$ lebih dipilih.

Selain itu, untuk mengetahui produk yang diminati wisatawan sebagai cinderamata wisata, dilakukan juga penyebaran kuesioner tertutup terhadap 205 orang responden yakni wisatawan yang berkunjung ke objek wisata di Kabupaten Pangandaran. Sektor pariwisata merupakan salah satu sektor penting dalam peningkatan Pendapatan Asli Daerah (PAD) dan pemberdayaan ekonomi masyarakat (Sunandar, 2016). Data kuesioner dari wisatawan diolah menggunakan sistem tabulasi.

Terakhir, untuk menggambarkan potensi pemberdayaan ekonomi dilakukan analisis profit cost ratio terhadap produk prospektif serta analisis deskriptif terhadap data yang diperoleh selama penelitian. Data yang digunakan adalah data primer yang diperoleh dari hasil wawancara dengan tiga orang pelaku usaha gula kelapa. Sementara itu, penggunaan metode deskriptif bermaksud untuk mencandra atau mendeskripsikan mengenai situasi atau kejadian secara sistematis, faktual dan akurat mengenai fakta dan sifat populasi (Harisudin, 2013). Untuk lebih jelasnya, tata laksana atau diagram alir penelitian ini dapat dilihat pada Gambar 2.

\section{HASIL DAN PEMBAHASAN}

\section{Analisis Situasional Potensi Agroindustri Berbasis Kelapa di Kabupaten Pangandaran \\ Kabupaten Pangandaran dengan luas wilayah 101.092 ha (BPS, 2018), memiliki visi yakni sebagai tujuan wisata termaju di Pulau Jawa (PerdaNo. 16 Tahun 2016), saat ini memiliki 10 kecamatan yakni Mangunjaya, Padaherang, Kalipucang, Pangandaran, Sidamulih, Parigi,}


Cigugur, Cijulang, Cimerak, dan Langkaplancar (BPS, 2018). Berdasarkan data dari Distan Kabupaten Pangandaran (2017), seluruh kecamatan tersebut memiliki perkebunan kelapa dengan luasan yang berbeda-beda, dimana perkebunan kelapa terluasnya berada di Kecamatan Cimerak dengan luas mencapai lebih dari 4 ribu ha atau sekitar $18 \%$ dari total luas lahan perkebunan kelapa di Kabupaten Pangandaran. Sementara itu, perubahan luas perkebunan kelapa, jumlah produksi kelapa dalam satuan butir dan ton kopra di Kabupaten Pangandaran pada periode 2014 - 2017 dapat dilihat pada Gambar 3.

Pada Gambar 3 dapat dilihat bahwa jumlah produksi dalam satuan ribu ton secara grafis tampak berbeda dengan jumlah produksi dalam satuan juta butir. Hal ini disebabkan oleh faktor konversi tingkat produksi kopra yakni untuk menghasilkan $1 \mathrm{~kg}$ kopra, rata-rata memerlukan 4 (empat) butir kelapa (Amin dan Prabandano, 2014).

Ketersediaan bahan baku hasil pertanian yang berasal dari produksi setempat menurut Satyajaya et al. (2016), akan mempermudah agroindustri untuk memperoleh bahan baku, jarak lebih dekat, dan harganya bisa lebih kompetitif. Berdasarkan hasil pengolahan data menggunakan metode peramalan moving average diprediksi bahwa potensi buah kelapa tahun 2018 di Kabupaten Pangandaran lebih dari 50 juta butir dengan nilai mean absolute deviation (MAD) sebesar 20 juta, standard error sekitar 42 juta dan mean absolute percent error sebesar $32 \%$.

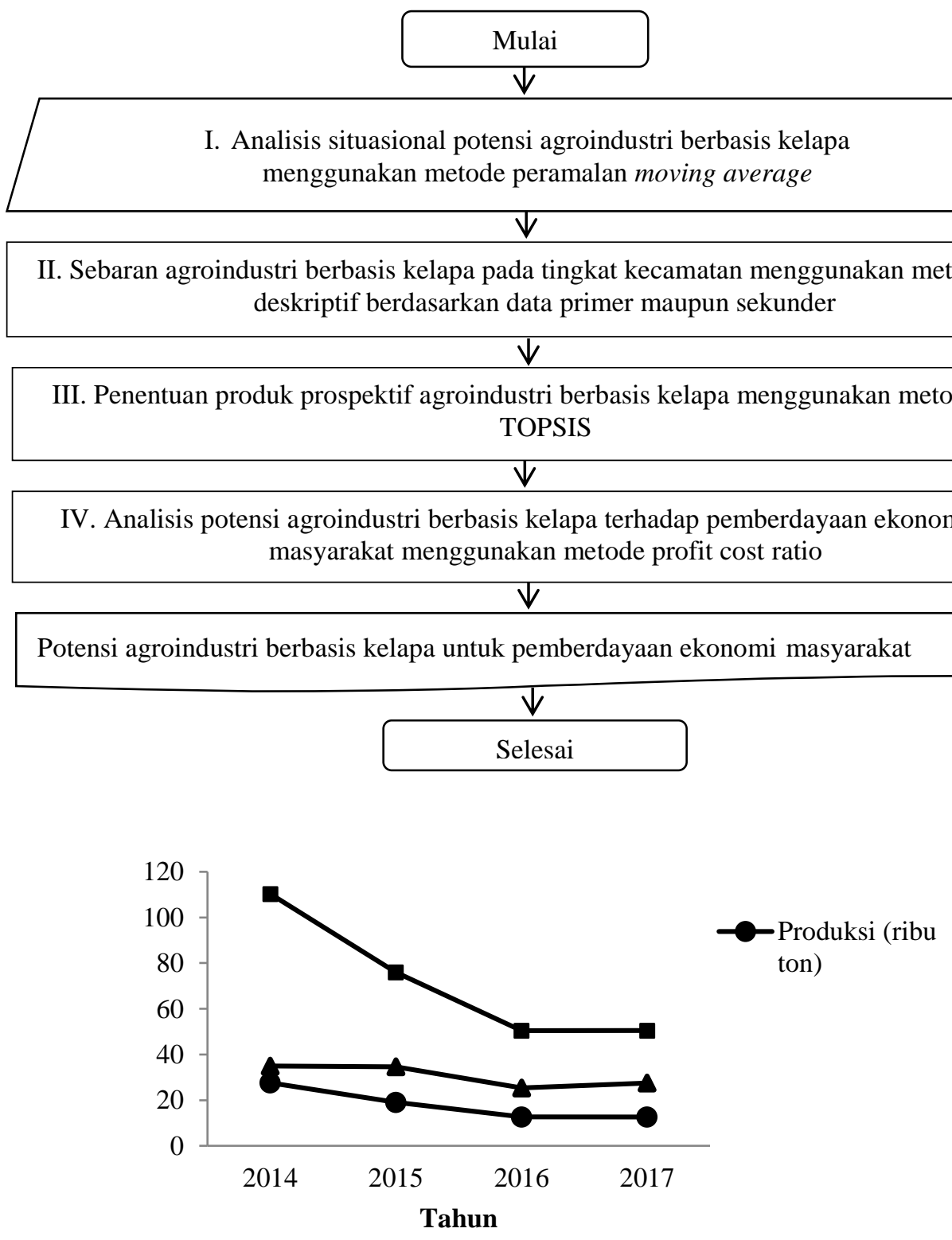

Sumber: Distan Kabupaten Pangandaran, 2017 (diolah)

Gambar 3. Jumlah produksi kelapa Kabupaten Pangandaran 2014 - 2017 
Hasil perhitungan memiliki angka kesalahan (error) yang tinggi karena data yang digunakan masih sedikit (hanya 4 periode). Namun demikian, berdasarkan hasil peramalan tersebut maka pada tahun 2018 potensi ketersediaan bahan baku untuk agroindustri berbasis kelapa yang menggunakan bahan baku dari buah kelapa adalah sama dengan dua periode sebelumnya yakni 50 juta butir.

Buah kelapa memiliki bobot yang bervariasi. Menurut Amin dan Prabandono (2014), bobot kelapa tua tidak kurang dari $2 \mathrm{~kg}$. Menurut Palungkun (2004), komposisi buah kelapa minimal terdiri dari sabut $25-32 \%$, tempurung $12-13,1 \%$, daging kelapa 28 - 34,9\%, dan air 19,2 - 25\%. Jika buah kelapa yang dihasilkan dikonversi ke dalam bobot rata-rata, maka akan dihasilkan kelapa dengan bobot total lebih dari 141 juta kg. Untuk selanjutnya, jika bobot tersebut dikonversi kembali menjadi bahan baku turunannya, maka akan diperoleh potensi ketersediaan bahan baku seperti yang dapat dilihat pada Tabel 3.

Sementara itu, menurut Mulyawan et al. (2015), komposisi sabut kelapa terdiri dari $25 \%$ gabus (cocopeat) dan $75 \%$ serat (coco fiber). Jika bobot sabut kelapa yang terdapat pada Tabel 3 dikonversi menjadi bagian-bagian penyusun sabut, maka akan diperoleh hasil seperti yang tampak pada Tabel 4.

Menurut Rukmayadi dan Marimin (2000) kelapa butiran dari Kabupaten Pangandaran merupakan kelapa yang memiliki kualitas tinggi. Kelapa butiran yang berkualitas ini juga yang menjadi salah satu pendorong berdirinya agroindustri berbasis kelapa di Kabupaten
Pangandaran dari berbagai skala industri. Selain ituberdasarkan hasil wawancara, diperoleh faktorfaktor lain yang berpotensi mendorong terhadap pertumbuhan agroindustri berbasis kelapa di Kabupaten Pangandaran adalah:

1. Ketersediaan dan kepastian pasokan bahan baku kelapa.

2. Ketersediaan sumber daya manusia.

3. Pangsa pasar yang luas.

4. Infrastruktur dan sarana transportasi.

5. Dukungan masyarakat sekitar.

6. Kebijakan pemerintah.

Selain perkebunan kelapa yang menghasilkan bahan baku berupa buah, terdapat pula perkebunan kelapa yang digunakan untuk memproduksi nira sebagai bahan baku produksi gula kelapa yang disebut dengan kelapa deres (sadap). Namun demikian, mengingat Kabupaten Pangandaran adalah daerah otonom baru, maka pendataan luas tanaman kelapa deres baru mulai dilakukan pada tahun 2016 sebagaimana dapat dilihat pada Tabel 5 .

Jenis kelapa deres yang ditanam adalah kelapa genjah. Menurut Mashud dan Matana (2014), dari tanaman kelapa genjah seluas 1 ha dengan jarak tanam 8,5 m x 8,5 m dan sistem tanam segiempat (138 pohon) maka dalam setahun dengan 300 hari sadap akan diperoleh nira sebanyak 82.800 L. Apabila rendemen 9,5\%, maka akan diperoleh produk gula sebanyak 7,9 ton. Bila data tersebut dikonversikan dengan luas tanaman kelapa genjah sadap yang ada di Kabupaten Pangandaran, maka potensi nira yang dihasilkan lebih dari 600 juta liter/tahun dan akan menghasilkan gula kelapa lebih dari 59 ribu ton/tahun.

Tabel 3. Potensi ketersediaan bahan baku berbagai produk dari buah kelapa

\begin{tabular}{lcc}
\hline \multicolumn{1}{c}{ Bahan Baku } & $\begin{array}{c}\text { Komposisi per Butir Kelapa } \\
(\boldsymbol{\%})\end{array}$ & $\begin{array}{c}\text { Bobot dari Total Produksi Kelapa } \\
\text { Pangandaran (ton) }\end{array}$ \\
\hline 1. Sabut & 35 & 49.481 \\
2. Daging Kelapa & 28 & 39.585 \\
3. Tempurung & 12 & 16.965 \\
4. Air & 25 & 35.344 \\
\hline
\end{tabular}

Sumber: Distan Kabupaten Pangandaran, 2017 (diolah)

Tabel 4. Potensi ketersediaan aneka bahan baku dari sabut kelapa

\begin{tabular}{lcc}
\hline \multicolumn{1}{c}{ Bahan Baku } & $\begin{array}{c}\text { Komposisi Penyusun Sabut } \\
\text { per Butir Kelapa (\%) }\end{array}$ & $\begin{array}{c}\text { Bobot dari Total Sabut } \\
\text { Kelapa Pangandaran (ton) }\end{array}$ \\
\hline 1. Coco fiber & 75 & 37.111 \\
2. Coco peat & 25 & 12.370 \\
\hline
\end{tabular}

Sumber: Distan Kabupaten Pangandaran, 2017 (diolah)

Tabel 5. Luas lahan kelapa deres di Kabupaten Pangandaran

\begin{tabular}{ccccc}
\hline \multirow{2}{*}{ Tahun } & \multicolumn{4}{c}{ Luas Lahan (ribu ha) } \\
\cline { 2 - 5 } & Tanaman Belum & Tanaman & Tanaman & \multirow{2}{*}{ Luas } \\
& Menghasilkan & Menghasilkan & Rusak & \\
\hline 2016 & 0,859 & 7,508 & 0,916 & 9,283 \\
2017 & 1,688 & 7,522 & 0,799 & 10,009 \\
\hline
\end{tabular}

Sumber: Distan Kabupaten Pangandaran, 2017 (diolah) 
Penyebaran Agroindustri Berbasis Kelapa di Kabupaten Pangandaran

Berdasarkan data yang diperoleh dari hasil survey lapangan dan Disnakerintrans Kabupaten Pangandaran, diketahui bahwa terdapat dua kategori agroindustri berbasis kelapayakni gula kelapa dan non gula kelapa. Agroindustri gula kelapatersebar di seluruh kecamatan, dengan jumlah terbesar terdapat di Kecamatan Cimerak. Jika dilakukan perbandingan terhadap data jumlah agroindustri berbasis kelapa di Kabupaten Pangandaran tahun 2017 dengan tahun 2016, maka jumlah agroindustri gula kelapa mengalami peningkatan sebesar $3,10 \%$, sedangkan untuk agroindustri kelapa non gula kelapa sebesar 22,22\% (Disnakerintrans, 2017).

Sementara itu, jumlah agroindustri berbasis kelapa non gula kelapa di setiap kecamatan belum terlalu banyak. Terdapat empat kecamatan yang mendominasi agroindustri berbasis kelapa non gula kelapa yakni Kecamatan Parigi, Kecamatan Padaherang, Kecamatan Cimerak dan Kecamatan Sidamulih. Khusus untuk di Kecamatan Parigi, terdapat satu agroindustri menengah kelapa terpadu yakni Koperasi Produsen Mitra Kelapa (KPMK) Pangandaran. KPMK Pangandaran menghasilkan produk berupa desiccated coconut, arang batok, briket arang batok, minyak kelapa, air kelapa, nata de coco, galendo, coco fiber dan cocopeat block. Di Kecamatan Sidamulih terdapat satu agroindustri besar kelapa terpadu yakni PT. Pacific Eastern Coconut Utama (PECU) yang menghasilkan produk yaitu coconut water, coconut cream,coconut cream powder, dan desiccated coconut. Berdasarkan data dari Disnakerintrans (2017), total agroindustri berbasis kelapa (kecil, menengah, besar) tahun 2017 sebanyak 3.802 unit, yang terdiri dari 3.725 unit agroindustri gula kelapa dan 77 agroindustri berbasis kelapa non gula kelapa. Agroindustri tersebut paling banyak terdapat di Kecamatan Cimerak yakni 1.588 unit, kemudian Kecamatan Kalipucang sebanyak 647 unit dan Kecamatan Padaherang sebanyak 579 unit. Sebaran agroindustri berbasis kelapa di Kabupaten Pangandaran pada tahun 2017 dapat dilihat pada Tabel 6 dan Gambar 4.

Tabel 6. Sebaran agroindustriberbasis kelapa di Kabupaten Pangandaran 2016 - 2017

\begin{tabular}{|c|c|c|c|c|c|c|}
\hline \multirow[t]{2}{*}{ Kecamatan } & \multicolumn{2}{|c|}{$\begin{array}{c}\text { Jumlah } \\
\begin{array}{c}\text { Agroindustri Gula } \\
\text { kelapa(Unit) }\end{array}\end{array}$} & \multirow[t]{2}{*}{$\begin{array}{c}\text { Peningkatan } \\
\text { Agroindustri Gula } \\
\text { kelapa }(\%)\end{array}$} & \multicolumn{2}{|c|}{$\begin{array}{c}\text { Jumlah } \\
\text { Agroindustri } \\
\text { Kelapa Non Gula } \\
\text { kelapa (Unit) }\end{array}$} & \multirow[t]{2}{*}{$\begin{array}{c}\text { Peningkatan } \\
\text { Agroindustri } \\
\text { KelapaNon Gula } \\
\text { kelapa }(\%)\end{array}$} \\
\hline & 2016 & 2017 & & 2016 & 2017 & \\
\hline Parigi & 83 & 83 & 0,00 & 12 & 16 & 33,33 \\
\hline Cijulang & 13 & 13 & 0,00 & 6 & 9 & 50,00 \\
\hline Cimerak & 1682 & 1577 & $-6,24$ & 11 & 11 & 0,00 \\
\hline Cigugur & 329 & 328 & $-0,30$ & 6 & 5 & $-16,67$ \\
\hline Langkaplancar & 100 & 122 & 22,00 & 2 & 2 & 0,00 \\
\hline Sidamulih & 105 & 125 & 19,05 & 9 & 11 & 22,22 \\
\hline Pangandaran & 100 & 115 & 15,00 & 2 & 4 & 100,00 \\
\hline Kalipucang & 526 & 644 & 22,43 & 3 & 3 & 0,00 \\
\hline Padaherang & 524 & 566 & 8,02 & 10 & 13 & 30,00 \\
\hline Mangunjaya & 151 & 152 & 0,66 & 2 & 3 & 50,00 \\
\hline Jumlah & 3613 & 3725 & & 63 & 77 & \\
\hline
\end{tabular}

Sumber: Disnakerintrans, 2017 (diolah)

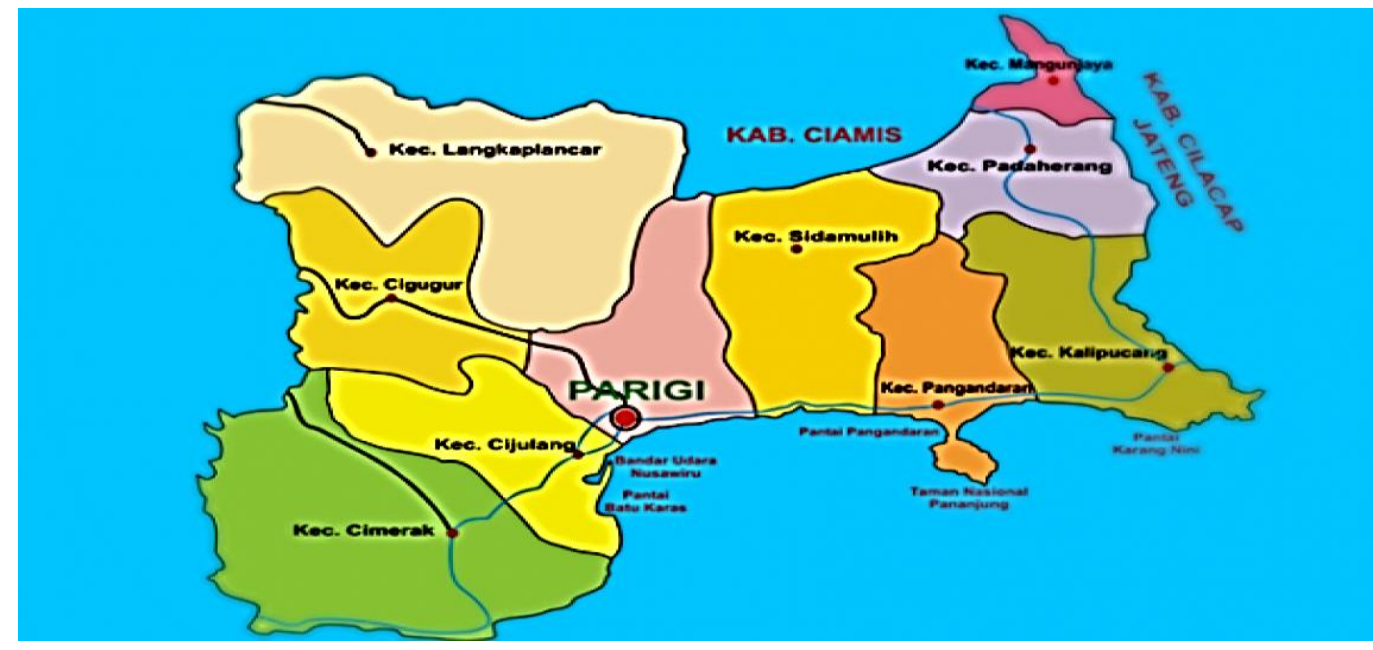

Gambar 4. Peta sebaran agroindustri berbasis kelapa di Kabupaten Pangandaran 2017 


\section{Pemilihan Produk Prospektif Agroindustri Berbasis Kelapa di Kabupaten Pangandaran}

Untuk meningkatkan PAD dan pendapatan masyarakat secara umum, maka pemerintah daerah harus mengidentifikasi potensi komoditas yang ada di daerah tersebut dan merumuskan program pengembangannya (Juhanis, 2012). Oleh karena itu, produk prospektif agroindustri berbasis kelapa di Kabupaten Pangandaran ditentukan dari produkproduk yang ada saat ini dan dihasilkan oleh agroindustri yang ada. Berdasarkan data dari Disnakerintrans (2017), terdapat 14 jenis produk agroindustri berbasis kelapa yang dihasilkan oleh IKM maupun industri besar yang ada di Kabupaten Pangandaran. Coconut milk, desiccated coconut, coconut water dan minyak kelapa adalah produk yang dihasilkan oleh industri besar, sedangkan sisanya dihasilkan oleh IKM. Jenis produk selengkapnya dapat dilihat pada Tabel 7.

Berdasarkan data pada Tabel 7 dapat dilihat bahwa agroindustri gula kelapa adalah yang paling dominan, disusul oleh nata de coco, produk kreatif lidi, dan kopra. Agroindustri berbasis kelapa terbanyak terdapat di Kecamatan Cimerak, kemudian Kalipucang dan Padaherang di tempat ketiga.

Sementara itu, untuk menentukan kriteria produk prospektif agroindustri berbasis kelapa digunakan kriteria gabungan dari Santoso dan Marimin (2001) serta Direktorat Jenderal Industri dan Dagang Kecil Menengah Departemen Perindustrian dan Perdagangan (2005), yaitu:

1. Kualitas produk.

2. Kekhasan produk.
3. Ketersediaan bahan baku.

4. Kemudahan teknologi.

5. Daya serap pasar.

6. Ketersediaan permodalan.

7. Kemudahan mendapatkan sumber daya manusia (SDM).

Hasil akhir pengolahan data kuesioner menggunakan metode TOPSIS dapat dilihat pada Tabel 8, dimana pada tabel tersebut dapat dilihat bahwa terdapat tiga alternatif produk yang memiliki nilai preferensi terbesar secara berurutan yaitu gula kelapa, kopra, dan minyak kelapa. Dengan demikian maka produk agroindustri berbasis kelapa yang paling prospektif adalah gula kelapa. Menurut Mugiono et al. (2014), agroindustri gula kelapa memiliki prospek yang cukup baik dan mampu meningkatkan pendapatan rumah tangga.

Sementara itu jika dikaitkan dengan keberadaan Kabupaten Pangandaran yang termasuk dalam KSP Jawa Barat, maka keberadaan agroindustri berbasis kelapa bersama-sama dengan pariwisata terpadu diharapkan mampu mendorong peningkatan ekonomi kawasan. Upaya yang dapat dilakukan antara lain dengan menjadikan produkproduk agroindustri berbasis kelapa sebagai produk kreatif yang khas dan dipasarkan di area objek wisata. Berdasarkan hasil penyebaran kuesioner terhadap wisatawan yang berkunjung ke beberapa objek wisata yang berada di Kabupaten Pangandaran, diperoleh data produk prospektif untuk dijadikan sebagai cinderamata wisata adalah produk dari batok kelapa (50\%), produk dari lidi (11\%) dan virgin coconut oil $(10 \%)$. Untuk lebih jelasnya dapat dilihat pada Gambar 5.

Tabel 7. Jenis agroindustri berbasis kelapa di Kabupaten Pangandaran tahun 2017

\begin{tabular}{lccccccccccc}
\hline \multicolumn{1}{c}{$\begin{array}{c}\text { Jenis Agroindustri } \\
\text { Berbasis Kelapa }\end{array}$} & \multicolumn{9}{c}{ Jumlah di Setiap Kecamatan (unit) } & \multicolumn{1}{c}{ Total } \\
\cline { 2 - 8 } (unit)
\end{tabular}

Sumber: Disnakerintrans, 2017 (diolah)

Keterangan:

$\mathrm{K} 1$ = Langkaplancar

$\mathrm{K} 2$ = Cigugur

$\mathrm{K} 3$ = Cimerak

$\mathrm{K} 4$ = Cijulang

$$
\begin{aligned}
& \text { K5 }=\text { Parigi } \\
& \text { K6 }=\text { Sidamulih } \\
& \text { K7 }=\text { Pangandaran } \\
& \text { K8 }=\text { Kalipucang }
\end{aligned}
$$

K9 = Padaherang

$\mathrm{K} 10=$ Mangunjaya 


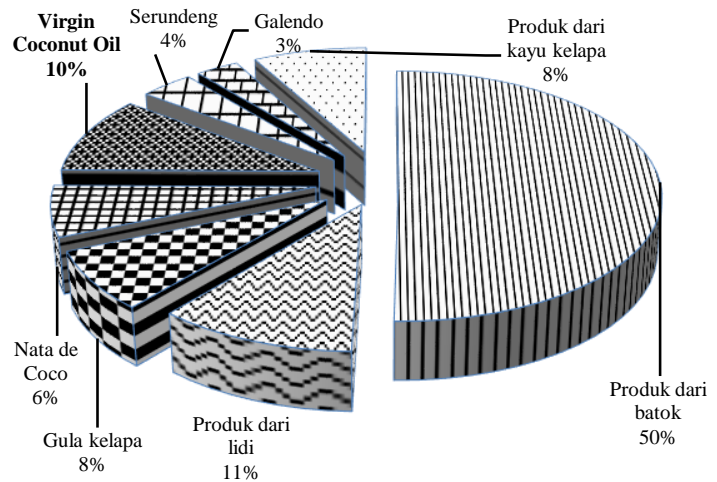

Gambar 5. Produk prospektif kelapa untuk cinderamata wisata

Berdasarkan hasil survey tersebut dapat dilihat bahwa produk dari batok kelapa merupakan produk industri kreatif yang paling diminati oleh wisatawan untuk dijadikan sebagai cinderamata. Menurut Balamurugan dan Rubini (2016), cinderamata adalah salah satu produk diversifikasi yang bisa dihasilkan dari kelapa. Hal ini sangat menarik untuk ditindaklanjuti karena batok merupakan limbah padat yang dihasilkan oleh agroindustri yang mengolah buah kelapa menjadi berbagai produk turunannya. Pemanfaatan limbah batok kelapa, mampu mengurangi permasalahan lingkungan dan menuju kepada konsep agroindustri yang zero waste. Konsep zero waste menurut Zaman dan Lehmann (2011) mencakup pemanfaatan seluruh sumber daya dari bahan limbah dan bertujuan untuk mendaur ulang $100 \%$ limbah padat yang dihasilkan dari suatu sistem. Kondisi ini juga mendorong lahirnya agroindustri kelapa terpadu sebagai salah satu alternatif untuk meningkatkan nilai tambah dan efisiensi usaha perkebunan kelapa rakyat (Hendrawati dan Syamsudin, 2016).

\section{Analisis Potensi Agroindustri Gula Kelapa untuk Pemberdayaan Ekonomi Masyarakat di Kabupaten Pangandaran}

Berdasarkan hasil pengolahan data pada tahap sebelumnya, diketahui bahwa Kabupaten Pangandaran memiliki potensi besar dalam hal ketersediaan bahan baku baik berupa buah kelapa maupun nira. Hal ini akan menjamin keberlangsungan agroindustri berbasis kelapa yang ada di Kabupaten Pangandaran yang tersebar di seluruh kecamatan.

Gula kelapa adalah produk prospektif agroindustri berbasis kelapa di Kabupaten Pangandaran. Faktor yang mempengaruhi produksi gula kelapa di antaranya jumlah produksi nira (Indarwati, 2009), kayu bakar, pekerja, kapur (Asmaida, 2009), terjaminnya pasar dan kontinuitas bahan baku (Budiarto, 2010). Oleh karena itu, pada bagian ini akan dibahas mengenai potensi agroindustri gula kelapa untuk pemberdayaan ekonomi masyarakat Kabupaten Pangandaran.
Prospek agroindustri gula kelapa menurut Santoso (1993) terbuka lebar, mengingat industri gula di Indonesia belum mampu memenuhi kebutuhan gula nasional. Bila dirata-ratakan, konsumsi gula kelapa adalah 4,5 kg/kapita/tahun, maka terdapat prospek yang cukup besar dengan jumlah penduduk Indonesia yang ada saat ini. Sementara itu untuk sektor industri, prospek pasar gula kelapajuga terbuka lebar khususnya untuk memenuhi kebutuhan industri kecap dan industri makanan lainnya yang terus meningkat. Di Kabupaten Pangandaran, saat ini beberapa pelaku IKM gula kelapa yang tergabung dalam Business Development Center (BDC) Pangandaran telah melakukan diversifikasi produk gula kelapa mangkuk menjadi beberapa produk lain seperti gula kelapa kemasan koin yang dipasarkan untuk cindera mata wisata dan gula semut yang dipasarkan selain untuk cindera mata wisata juga untuk restoran, perhotelan dan perkantoran. Dengan demikian, peluang pasar gula kelapa dapat terus diupayakan untuk ditingkatkan dan akan semakin terbuka lebar di masa yang akan datang.

Dari segi pemasaran, terdapat tiga pola tata niaga gula kelapa, yaitu:

1. Hasil produksi IKM gula kelapa ditampung melalui pedagang pengepul (pola I). Selanjutnya pedagang pengepul menjualnya ke pedagang besar atau pabrik kecap.

2. Hasil produksi IKM gula kelapa dijual melalui pedagang pengecer (pola II). Selanjutnya pedagang pengecer menjualnya ke konsumen akhir di pasar tradisional.

3. Hasil produksi IKM gula kelapa dijual langsung oleh IKM kepada konsumen tanpa melalui perantara (pola III).

Tata niaga di atas menunjukkan bahwa struktur pasar gula kelapa di Kabupaten Pangandaran adalah monopsoni. Dengan struktur pasar monopsoni ini maka pedagang perantara berada dalam posisi yang dominan dalam pembentukan harga sedangkan produsen berada dalam posisi sebagai penerima harga (Maharani et al., 2011). Tata niaga gula kelapa di Kabupaten Pangandaran dapat dilihat pada Gambar 6.

Untuk pola tata niaga seperti yang tampak pada Gambar 6, yang paling menguntungkan bagi IKM gula kelapa adalah tata niaga pola III.Tanpa melalui perantara, maka keuntungan yang diperoleh IKM menjadi lebih besar karena bisa menjual gula kelapa dengan harga pasar kepada konsumen akhir.

Berdasarkan hasil wawancara dengan tiga orang pelaku agroindustri gula kelapa yakni IKM terkecil dengan kapasitas produksi $23 \mathrm{~kg} / \mathrm{hari}$, dikerjakan sendiri oleh pemilik IKM tersebut (biaya tenaga kerja dianggap nol), jumlah pohon yang disadap sebanyak 100 pohon dan pohon kelapanya menyewa kepada pemilik kebun, maka dapat dihitung profitabilitasnya seperti yang terdapat pada Tabel 9. 


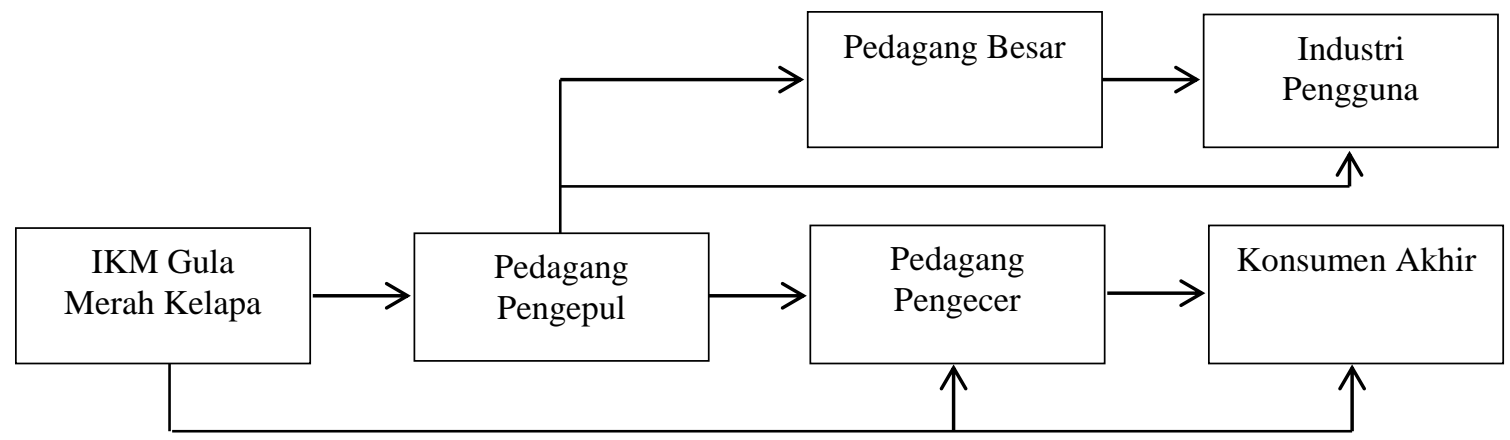

Gambar 6. Tata niaga gula kelapa di Kabupaten Pangandaran

Tabel 9. Profitabilitas setiap tata niaga gula kelapa di Kabupaten Pangandaran

\begin{tabular}{lccc}
\hline \multicolumn{1}{c}{ Deskripsi } & \multicolumn{3}{c}{ Tata Niaga } \\
\cline { 2 - 4 } & Pola I & Pola II & Pola III \\
\hline 1. Total Produksi (Kg/bulan) & 690 & 690 & 690 \\
2. Biaya Produksi: & & & \\
a. Sewa Pohon Kelapa (ribu rupiah/bulan) & 2.140 & 2.140 & 2.140 \\
b. Biaya Bahan Bakar (ribu rupiah/bulan) & 960 & 960 & 960 \\
c. Biaya transportasi dan lainnya (ribu rupiah/bulan) & 80 & 80 & 80 \\
3. Total Biaya Produksi (ribu rupiah/bulan) & 3.180 & 3.180 & 3.180 \\
4. Biaya Produksi per kilogram (Rp) & 4.609 & 4.609 & 4.609 \\
5. Harga Jual (Rp/kg) & 10.700 & 12.000 & 14.000 \\
6. Total Pendapatan (ribu rupiah/bulan) & 7.383 & 8.280 & 9.660 \\
7. Profit (ribu rupiah/bulan) & 4.203 & 5.100 & 6.480 \\
8. Profit per kilogram (Rp) & 6.091 & 7.391 & 9.391 \\
9. Profit per cost (P/C) & 1,32 & 1,60 & 2,04 \\
\hline
\end{tabular}

Dari Tabel 7 terlihat bahwa biaya produksi gula kelapa berada pada kisaran Rp. 4.000/kg. Biaya produksi ini relatif sama dengan biaya produksi yang ada pada agroindustri gula kelapa yang ada di Kabupaten Cilacap (Santoso et al., 2016). Sementara itu, P/C dari seluruh pola tata niaga menunjukkan nilai di atas satu, sehingga dapat dikatakan bahwa dengan pola tata niaga manapun agroindustri gula kelapa berpotensi memberikan keuntungan dan memiliki potensi peningkatan kesejahteraan masyarakat di Kabupaten Pangandaran.

Secara umum, agroindustri berbasis kelapa berpeluang untuk meningkatkan pendapatan (Wardanu dan Anhar, 2014) dan potensi peningkatan kesejahteraan masyarakat juga dapat dilihat dari penyerapan tenaga kerja (Nasir dan Yuslinaini, 2017). IKM gula kelapa secara umum dikelola oleh rumah tangga. Bila dalam satu rumah tangga terlibat dua orang tenaga kerja, maka pada tahun 2016 sektor ini telah menyerap tenaga kerja sebanyak 7.226 orang, sedangkan pada tahun 2017 sebanyak 7.450 orang tenaga kerja. Jumlah tenaga kerja akan bertambah lagi jika diperhitungkan juga tenaga kerja yang terlibat secara tidak langsung dengan IKM gula kelapa, seperti pengepul, pedagang, tenaga kerja di sektor transportasi, dan pergudangan. Aspek penting lain adalah bahwa keberadaan IKM gula kelapa telah menjadi mata pencaharian sebagian penduduk di
Kabupaten Pangandaran dan merata di setiap kecamatan.

Potensi keuntungan juga akan bertambah besar jika dilakukan diversifikasi produk. Menurut Umar (2016), diversifikasi produk gula kelapa adalah salah satu strategi yang dapat digunakan untuk mengembangkan agroindustri gula kelapa. Salah satu produk diversifikasi gula kelapa adalah gula semut. Agroindustri gula semut berpotensi untuk meningkatkan pendapatan produsengula kelapa (Pardani, 2015). Jika gula kelapa didiversifikasi menjadi gula semut, maka harga di pedagang pengepul per $\mathrm{kg}$ berada pada kisaran Rp. 14.500 - Rp. 15.500 bergantung kepada kualitas gulanya.Khusus untuk gula semut kelapa, tata niaga yang ada saat ini adalah IKM gula kelapa menjualnya melalui BDC dan selanjutnya dikemas oleh BDC dengan kemasan khusus dan dipasarkan ke restoran, perhotelan, perkantoran serta gerai khusus yang berada di objek wisata Pantai Pangandaran. Alternatif diversifikasi lainnya adalah gula kelapa didiversifikasi menjadi gula kelapa kristal. Menurut Arumsari dan Syamsiar (2011), selain memiliki mutu yang lebih baik, pangsa pasar gula kelapa kristal juga sangat terbuka lebar, tidak hanya untuk pasar lokal namun juga untuk ekspor.

Namun demikian, karena agroindustri gula kelapa merupakan salah satu agroindustri yang 
produknya adalah bahan makanan atau bahan baku industri makanan, maka memiliki tantangan khusus yang harus dihadapi dan diatasi. Tantangan tersebut menurut Garnett (2012) adalah tantangan produksi melalui peningkatan efisiensi, tantangan konsumsi melalui pengaturan permintaan, dan tantangan sosioekonomi yakni memperbaiki tata kelola. Di sisi lain, menurut Rosepa et al. (2014) terdapat juga kendala lain yang dihadapi oleh IKM gula kelapa yakni teknologi pengolahan gula kelapa yang sederhana sehingga kapasitas produksi menjadi terbatas.

Berdasarkan gambaran di atas, terlihat bahwa pengembangan agroindustri gula kelapa di Kabupaten Pangandaran dengan pola tata niaga yang ada saat ini, memberikan potensi keuntungan bagi masyarakat pelaku IKM gula kelapa dan masyarakat lain yang berhubungan dengan IKM tersebut. Dengan jumlah produksi yang tidak sedikit dan pangsa pasar yang terbuka lebar, membuat IKM gula kelapa memiliki potensi untuk menggerakan sektor lain seperti transportasi dan distribusi, pergudangan, suplai bahan baku dan pembantu, serta industriindustri lain yang menggunakan gula kelapa sebagai bahan bakunya. Kondisi seperti ini menurut Oktaliando et al. (2013) dikenal sebagai efek keterkaitan antar industri (interindustry linkage effect) yang mengarah ke belakang dan ke depan.

Di samping itu, pengembangan agroindustri, termasuk agroindustri berbasis kelapa, akan mampu mengembangkan berbagai kegiatan dalam sistem agribisnis dari hulu hingga ke hilir secara keseluruhan, sehingga memberikan pengaruh besar bagi pencapaian berbagai tujuan pembangunan daerah (Junaidi et al., 2014). Dengan demikian maka agroindustri gula kelapa memiliki potensi yang menguntungkan serta peranan penting dalam perputaran roda perekonomian dan kesejahteraan masyarakat di Kabupaten Pangandaran Jawa Barat.

\section{KESIMPULAN DAN SARAN}

\section{Kesimpulan}

Agroindustri berbasis kelapa memiliki potensi yang besar dalam pemberdayaan ekonomi masyarakat di Kabupaten Pangandaran. Potensi ini dapat dilihat dari jumlah ketersediaan dan kepastian pasokan bahan baku kelapayakni 50 juta butir, kualitas kelapa yang dihasilkan, ketersediaan sumber daya manusia, pangsa pasar yang luas, infrastruktur dan sarana transportasi, dukungan masyarakat sekitar, hingga adanya kebijakan pemerintah daerah yang mendukung pertumbuhan agroindustri berbasis kelapa. Agroindustri berbasis kelapa tersebar di seluruh kecamatan, dengan jumlah terbanyak terdapat di Kecamatan Cimerak sebanyak 1.588 unit. Produk agroindustri berbasis kelapa yang paling prospektif adalah gula kelapa. Nilai P/C berada pada kisaran 1,32 sampai 2,04 sehingga produk gula kelapa memiliki potensi yang besar untuk pembedayaan ekonomi masyarakat di Kabupaten Pangandaran Jawa Barat.

\section{Saran}

Penelitian ini masih memerlukan kajian lebih lanjut mengenai jaminan keberlanjutan pasokan bahan baku di tengah maraknya alih fungsi lahan pertanian dan perkebunan, penerapan teknologi yang tepat guna dalam rangka meningkatkan produksi dan keragaman produk, serta profil setiap jenis agroindustri berbasis kelapa agar mampu menarik investor untuk mengembangkan agroindustri berbasis kelapa.

\section{UCAPAN TERIMA KASIH}

Terima kasih disampaikan kepada Lembaga Pengelola Dana Pendidikan (LPDP) yang telah membiayai penelitian ini melalui Beasiswa Unggulan Dosen Indonesia Dalam Negeri (BUDIDN).

\section{DAFTAR PUSTAKA}

Abuya WO. 2013. What is in a coconut? An ethnoecological analysis of mining, social displacement, vulnerability, and development in rural Kenya. Journal African Studies Quarterly. 14 (1 \& 2): 1-21.

Amin S dan Prabandano K. 2014.Cocopreneurship Aneka Peluang Bisnis dari Kelapa. Yogyakarta: Lily Publisher.

Arumsari V dan Syamsiar S. 2011. Pemberdayaan masyarakat perdesaan berbasis agroindustri pangan lokal(suatu kajian agroindustri gula kelapa kristal di Kecamatan Kokap Kabupaten Kulon Progo Propinsi Daerah Istimewa Yogyakarta). Jurnal Sosial Ekonomi Pertanian Agribisnis. 8 (1): 35-41.

Asmaida. 2009. Faktor-faktor yang mempengaruhi produksi gula kelapa(studi kasus industri rumah tangga di Desa Sungai Gembar Kecamatan Betara Kabupaten Tanjung Jabung Barat). Jurnal Ilmiah Universitas Batanghari Jambi. 9 (2): 66 - 70.

Badan Pusat Statistik Provinsi Jawa Barat. 2017. Provinsi Jawa Barat dalam Angka 2017.Bandung:BPS Provinsi Jawa Barat.

Badan Pusat Statistik Kabupaten Ciamis. 2018. Kabupaten Pangandaran dalam Angka 2018. Bandung: BPS Kabupaten Ciamis.

Balamurugan V dan Rubini M. 2016.Problems in production and marketing of coconut in Theni District. Journal Advances in Business Management. 2 (4): 182 - 185.

Budiarto. 2010. Pembangunan ekonomi perdesaan melalui agroindustri: penentuan prioritas pengembangan jenis agroindustri kelapa di Kabupaten Kulonprogo. Jurnal Sosial Ekonomi Pertanian Agribisnis. 7 (1): 6-14. 
Chen CT. 2000. Extensions of the TOPSIS for group decision-making under fuzzy environment. Journal Fuzzy Sets and Systems. 114 (1): 19.

Dinas Perindustrian Tenaga Kerja dan Transmigrasi Kabupaten Pangandaran. 2017. Data Potensi Industri Kecil dan Menengah Kabupaten Pangandaran 2017. Pangandaran: Dinas Perindustrian Tenaga Kerja dan Transmigrasi Kabupaten Pangandaran.

Dinas Pertanian Kabupaten Pangandaran. 2017. Angka Tetap Statistik Perkebunan 2017. Pangandaran: Dinas Pertanian Kabupaten Pangandaran.

Direktorat Jenderal Industri Dagang Kecil dan Menengah.2005. Pedoman Pelaksanaan Pembinaan IKM Pangan. Jakarta: Direktorat Jenderal Industri Dagang Kecil dan Menengah.

Direktorat Jenderal Perkebunan Kementerian Pertanian. 2017. Statistik Perkebunan Indonesia 2015 - 2017 Kelapa. Jakarta: Direktorat Jenderal Perkebunan Kementerian Pertanian.

Elida S. 2017. Pemetaan pertanian potensial dalam pengembangan agroindustri unggulan di Kabupaten Kepulauan Meranti. Jurnal Gontor Agrotech Science. 3 (1): 73-93, doi: 10.21111 .

Garnett T. 2012. Food Sustainability: Problems, Perspectives and Solutions. Proceedings of A Meeting of the Nutrition Society. King's College Conference Centre, University of Aberdeen.26-27 Maret 2012.

Gaspersz V. 2005.Production Planning and Inventory Control. Jakarta: Gramedia Pustaka Utama.

Harisudin M. 2013. Pemetaan dan strategi pengembangan agroindustri tempe di Kabupaten Bojonegoro, Jawa Timur. Jurnal Teknologi Industri Pertanian. 23 (2): 120128.

Hendrawati TY dan Syamsudin. 2016. Analisis kelayakan industri kelapa terpadu. Jurnal Teknologi. 8 (2): 61-70.

Hwang C dan Yoon K. 1981. Multiple Attribute Decision Making: Methods and Applications. New York: Springer-Verlag.

Indarwati I. 2009.Efisiensi produksi pada agroindustri gula kelapa di Kecamatan Cilongok Kabupaten Banyumas. Jurnal Ilmiah Ekonomika. 12 (3): 109 - 179.

Juhanis. 2012. Pengaruh sektor unggulanterhadap pertumbuhanekonomi wilayah Kabupaten Halmahera Selatan. Jurnal Plano Madani. 1 (1): $16-28$.

Junaidi, Amir A, dan Hardiani. 2014. Potensi klaster agroindustri usaha mikro kecil dan menengah di Provinsi Jambi. Jurnal
Perspektif Pembiayaan dan Pembangunan Daerah.2 (1): 9 - 20.

Maharani E, Edwina S, dan Kusumawaty Y. 2011.Pemasaran gula kelapa di Kabupaten Indragiri Hilir melalui pendekatan struktur, perilaku dan penampilan pasar.Indonesian Journal Agricultural Economics. 2 (1): 87104.

Marimin dan Maghfiroh N. 2013.Aplikasi Teknik Pengambilan Keputusan dalam Manajemen Rantai Pasok. Bogor: IPB Press.

Mashud N dan Matana Y. 2014. Kelapa genjah sebagai sumber nira untuk pembuatan gula. prosiding Konferensi Nasional Kelapa VIII. Jambi: 21-22 Mei 2014.

Moorthi C. 2012. A study on production and marketing of coconut in Tamilnadu with special reference to Thanjavur District. [Disertasi]. Tamilnadu: Khadir Mohideen College.

Mugiono, Marwati S, dan Awami SN. 2014. Analisis pendapatan usaha gula kelapa (studi kasus di Desa Medono Kecamatan Kaliwiro Kabupaten Wonosobo). Jurnal Mediagro. 10(2): 22-31.

Mulyawan, M, Setyowati, dan Widjaja E, A.2015. Surfaktan sodium ligno sulfonat (SLS) dari debu sabut kelapa. Jurnal Teknik ITS. 4 (1): $1-3$.

Nasir dan Yuslinaini. 2017. Analisis pemetaan industri kreatif subsektor kerajinan sertadampak peningkatkan kesejahteraan masyarakat diKabupaten Aceh Besar. Jurnal. Ekonomi dan Manajemen Teknologi. 1(1): 11-17.

Oktaliando R, Hudoyo A, dan Soelaiman A. 2013. Analisis keterkaitan sektor agroindustri terhadap perekonomian di Provinsi Lampung. Jurnal Ilmu-Ilmu Agribisnis. 1 (1): $16-24$.

Palungkun R. 2004. Aneka Produk Olahan Kelapa. Jakarta: PT. Penebar Swadaya.

Pardani C. 2015. Peningkatan pendapatan perajin gula melalui agroindustri gula semut di Kabupaten Tasikmalaya. Jurnal Mimbar Agribisnis. 1 (1): 23-29.

Peraturan Daerah Kabupaten Pangandaran Nomor 16 Tahun 2016 tentang Rencana Pembangunan Jangka Menengah Daerah (RPJMD) 2016 2021.

Rosepa P, Affandi MI, dan Adawiyah R. 2014. Analisis kelayakan pengembangan agroindustri gula kelapa skala mikro di Kabupaten Lampung Timur. Jurnal IlmuIlmu Agribisnis. 2 (2): 150 - 157.

Rukmayadi D dan Marimin. 2000. Seleksi produk kelapa prospektif dan analisismutunya dengan pendekatan fuzzy. Jurnal Ilmu Pertanian Indonesia. 9 (2): 52-61. 
Rukmayadi D. 2016. Model logistikramah lingkungan agroindustri karet. [Disertasi]. Bogor: Institut Pertanian Bogor.

Rusdi M. 2014. Analisis data sekunder dalam pemetaanpotensi ekonomi berbasis kelurahan atau desa di Kabupaten Buru. Jurnal Societas Fisip - Unmus. 3(1): 1-27.

Santoso I dan Marimin. 2001. Penentuan produk olahan apel unggulan menggunakan teknik fuzzy non numerik dan analisis struktur serta pola pembinaan kelembagaannya. Jurnal Teknologi dan Industri Pangan. 12(2): $163-170$.

Santoso H, Budiningsih S, dan Dumasari. 2016. Pola kemitraan agroindustri gula kelapa di Desa Bantar Kecamatan Wanareja Kabupaten Cilacap. Jurnal Agritech. 27 (1): 48 - 59.

Santoso HB. 1993. Pembuatan Gula Kelapa. Yogyakarta: Penerbit Kanisius.

Sari RP, Santoso AJ, dan Ernawati. 2014. Perancangan Sistem Pendukung Keputusan Kelompok Metode TOPSIS dan Borda Untuk Evaluasi Kegiatan Penanganan Infrastruktur Jalan. Prosiding Seminar Nasional Teknologi Informasi dan Komunikasi $2014 \quad$ (SENTIKA 2014).Yogyakarta: 15 Maret 2014.

Satyajaya W, Suroso E, Al Rasyid H, Utomo TP. 2016. Kajian penentuan komoditas unggulan dalam pengembangan teknologi agroindustri rakyat di Kabupaten Tulang Bawang. Jurnal Kelitbangan Inovasi dan Pembangunan. 4 (1): 22-36.

Sivapragasam A. 2008. Coconut in Malaysia current developments and potential for revitalization. Proceedings of the $2^{\text {nd }}$ International Plantation Industri Conference and Exhibition (IPICEX 2008). Shah Alam Malaysia: 18-21 November 2008.
Sunandar DM. 2016. Kajian implementasi bauran pemasaran kepariwisataan dalam upaya peningkatan kunjungan wisata dan implikasinya terhadap pendapatan asli daerah dan pemberdayaan ekonomi masyarakat(studi di pantai wisata Pangandaran Jawa Barat). [Disertasi]. Bandung: Universitas Pasundan Bandung.

Supratma RME dan Erli KDM. 2013. Penentuan kawasan agroindustri berdasarkan komoditas unggulan di Kabupaten Bondowoso. Jurnal Teknik POMITS. 2 (2): $109-113$.

Umar, ZA. 2016. The development strategy of coconut sugar industry. International Journal Engineering and Science. 5 (3): 58 $-66$.

Wardanu AP dan Anhar M. 2014. Strategi pengembangan agroindustri kelapa sebagai upaya percepatan ekonomi masyarakat di Kabupaten Ketapang. Jurnal Industria. 3 (1): $13-26$.

Windarto AP.2017. Implementasi metode TOPSIS dan SAW dalam memberikan reward pelanggan. Jurnal Ilmu Komputer. 4 (1): 88 $-101$.

Wulandari S dan Ma'arif S. 2009.Analisis Peluang dan Tantangan Pengembangan Agroindustri Kelapa. Jurnal Agrointek. 4 (1): 28 - 38.

Zaman AU dan Lehmann S. 2011.Challenges and opportunities in transforming a city into a “zero waste city”. Jurnal Challenges. 2: 7393, doi:10.3390.

Zulgani, Syafaruddin dan Parmadi. 2014. Analisis daya saing produk agroindustri subsektor perkebunan dalam perekonomian wilayah Provinsi Jambi. Jurnal Perspektif Pembiayaan dan Pembangunan Daerah. 2 (1): $29-38$. 